\title{
Late Holocene evolution of the southwestern Donana National Park (Guadalquivir Estuary, SW Spain): a multivariate approach
}

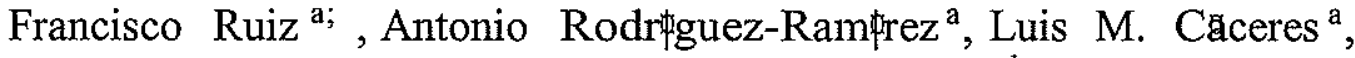

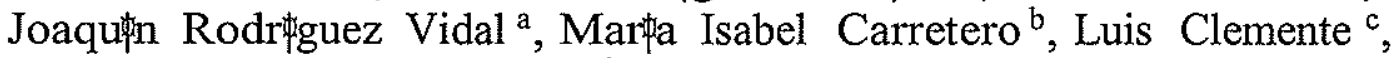 \\ Juan M. Mun oz ${ }^{d}$, Celia Yanez ${ }^{c}, M$. Abad ${ }^{a}$ \\ a Departamento de Geodinåmica y Paleontologła, Universidad de Huelva, Avda. Fuerzas Armadas, s/n, 21071 Huelva, \\ Spain \\ b Departamento de Cristalografła, Mineralogła y Quł̇ica Agrłcola, Universidad de Sevilla, Apdo. 553, Sevilla, \\ Spain \\ c Departamento de Geoecologła, I.R.N.A.S.E., C.S.I.C., Avda. Reina Mercedes, s/n, 41012 Sevilla, \\ Spain \\ d Departamento de Estadłstica e Investigacion Operativa, Universidad de Sevilla, Avda. Reina Mercedes, s/n, 41071 Sevilla, \\ Spain
}

\begin{abstract}
Four phases are distinguished in the Late Holocene evolution of the southwestern Don ana National Park (SW Spain), based on a multidisciplinary analysis of the sediments present in drill cores. In the oldest phase ( $\mathbf{s} 2400^{\wedge} 2500$ cal. yr BP), a coastal lagoon (the Roman Lacus Ligustinus) was recognized in the central part of this area, partly closed by the Don ana spit and limited by fluvial levees. The following phase (V2400^2200 cal. yr BP) is characterized by high-energy events, which caused the breakthrough of the Don ana spit and the creation of new littoral strands in the inner areas. In the third phase $\left(\mathrm{V} 2200^{\wedge} 2050 \mathrm{cal}\right.$. yr BP), this new outlet was closed, coinciding with the progradation of the Don ana spit. The last phase (V2050 cal. yr BP^Recent) comprises three periods : (a) an unstable period (V2050^1950 cal. yr BP), with the deposit of cheniers over the previous levees; (b) an infilling period, with a diminution of the marine influence; and (c) the appearance of temporary ponds between the emerged levees and cheniers.
\end{abstract}

Keywords: geomorphology; mineralogy ; paleontology; estuarine evolution ; Late Holocene ; SW Spain

\section{Introduction}

The evolution of coastal environments (estuaries, deltas, fjords) is the result of the interaction between the original geomorphology, waves, tides and fuvial supplies, with modiccations derived from relative sea-level changes, climatic setting or human activities (Davies, 1964; Chiverrell, 2001). This interaction may cause changes in the local sedimentation rates, the creation of new geomorphological formations (spits, cheniers, levees), sudden biological crises or an alteration of the 
natural hydrodynamics (Gerdes et al., 2003; Leduc et al., 2002; Ybert et al., 2003). For a detailed dednition of these changes, it is necessary to combine the analyses of geomorphological, sedimentological, faunal and mineralogical features in order to determine past environmental evolutions in these littoral areas (Chamley, 1989; Dalrymple et al., 1992; De la Vega et al., 2000; Edwards, 2001; Umitsu et al., 2001).

These geological investigations can be completed with datings which might lead to a revision of the historical record. Knowledge of the geological evolution is very useful to obtain information about old marine connections (Kristensen et al., 1995), beginning, end or impact of man's interventions (Favero and Serandrei, 1981; Albani et al., 1995; Favero et al., 1995), changes in paleoenvironmental conditions (Albertotanza et al., 1977; Angliano et al., 2000) or the recning of radiocarbon ages (Borja et al., 1999).

Along the southwestern Spanish coast, there are four estuaries (Fig. 1: Guadiana, Piedras, Tinto-Odiel, Guadalquivir) partly enclosed by spits. A number of studies have concentrated on the Holocene evolution of this littoral area, suggesting a chronology of events of progradation and erosion based on the radiocarbon dating of shells collected from these spits (Zazo et al., 1994; Lario et al., 1995; Goy et al., 1996; Rodrłguez-Ramłrez, 1996; Rodrłguez-Ram中rez et al., 1996; Dabrio et al., 1999). Two major Holocene phases of coastal progradation have been recognized after the transgressive maximum (6500 cal. yr BP; Zazo et al., 1994), including four spit systems. The limits for progradation of the spit units, with a reservoir correction (3440 Q 85 yr; Dabrio et al., $1999)$, are $6500^{\wedge} 4400$ cal. yr BP, $4200^{\wedge} 2550$ cal. yr BP, $2300^{\wedge} 800$ cal. yr BP and 500 cal. yr BP to the present. These phases are divided by erosional events at $4500^{\wedge} 4200$ cal. yr BP, $2600^{\wedge} 2300$ cal. yr $\mathrm{BP}$ and $1100^{\wedge} 1000 \mathrm{cal}$. yr BP. Other studies have investigated the Holocene estuarine facies (Borrego, 1992; Morales, 1993) and the reconstruction of the Holocene sedimentary evolution based on drill cores (Borrego et al., 1999; Dabrio et al., 2000).

The Guadalquivir River is the most important £uvial stream of this zone. The crst historical de- scription of its estuary was made by the Roman chronicler Strabo in his work Geographica, written between 29 and $7 \mathrm{BC}$. He referred to the southern part of this estuary as an inland lagoon (Lacus Ligustinus), a paleogeography con $\measuredangle$ rmed 40 years later by Mela, a Spanish chronicler, in his work De Chorographia (Garcła Bellido, 1987). Most recently (19th ${ }^{\wedge} 20$ th centuries), studies of this area have been centered on its exceptional biological assemblages whereas little information is found about the geological evolution (e.g., Carretero et al., 2002), a fundamental basis to understand the recent ecological expansion.

In this paper, we perform an integrated, geological analysis of the southwestern part of this estuary, using geomorphological techniques, radiometrically dated cores, lithostratigraphic and biotic analyses (macrofossils, ostracodes) and mineralogical data. The main aim is to specify the environmental changes occurring in this historical lagoon in the last millennia, which may explain the recent geomorphological features of the Don ana National Park, a privileged biological site in southwestern Spain. Other investigations carried out in the remaining estuaries of this coast were conducted in order to compare the chronology of the main events which happened during the Late Holocene in this area.

\section{The Guadalquivir estuary}

The Guadalquivir River (560 km long) drains a catchment of $57000 \mathrm{~km}^{2}$, comprising mainly Tertiary sedimentary rocks. This river is partly blocked in the lower reach by sandy barriers, resulting in a large estuary $\left(1800 \mathrm{~km}^{2}\right)$. In the southwestern sector (Fig. 1), this estuary includes the Don ana National Park, a UNESCO-MAB Biosphere Reserve. This site is one of the largest wetlands (50720 ha) in Europe and represents the last tract of relatively undisturbed marsh in this system.

Fluvial regime, tidal £ux, wave action and drift currents control the hydrodynamic processes. This river is the main sediment source of the southwestern Spanish coast, with a mean annual discharge of $164 \mathrm{~m}^{3} / \mathrm{s}$. The highest runoi ( $\mathrm{s} 1000$ 


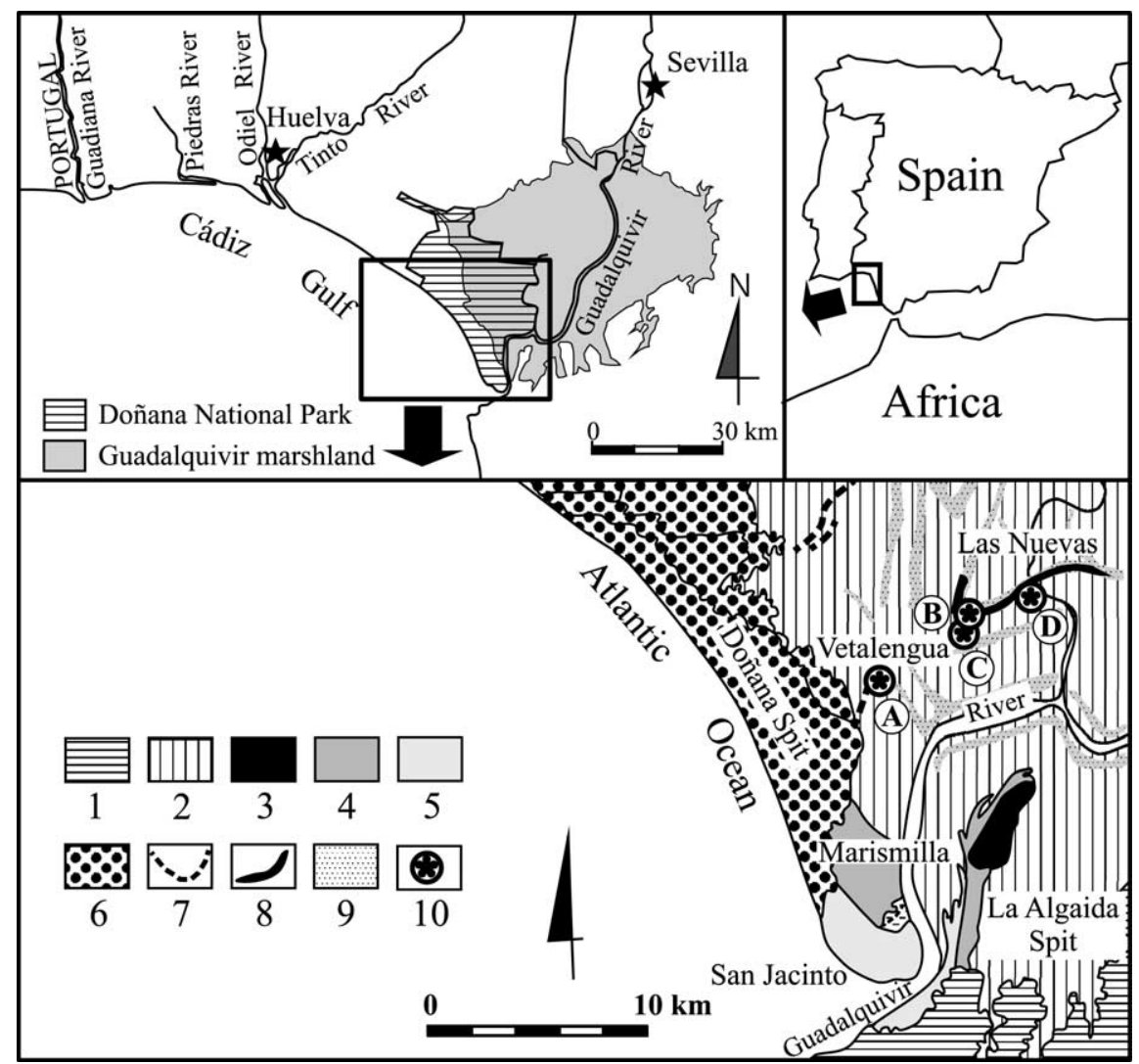

Fig. 1. Geographical setting and geomorphology of the Guadalquivir River mouth. Key: 1: Plio^Quaternary substrate ; 2: marshes; $3^{\wedge} 5$ : progradational phases of the littoral spits; 6: Quaternary dune systems; 7: littoral ridges; 8: estuarine ridges; 9: clayey levees; 10: location of the drillings studied $\left(A^{\wedge} D\right)$.

$\mathrm{m}^{3} / \mathrm{s}$ ) occurs from January to February, when the propagation velocity of the discharge peaks rises upto $1 \mathrm{~m} / \mathrm{s}$ (Vanney, 1970; Menanteau, 1979)

The tidal regime is mesotidal and semidiurnal, with an average tidal range of approximately $3.6 \mathrm{~m}$ (Borrego et al., 1993). Dominant waves associated with the Atlantic circulation come from the southwest, with a medium wave energy because $75 \%$ of the waves do not exceed $0.5 \mathrm{~m}$ in height. These conditions favor the development of broad lowlands, usually sheltered by spits, where tidal £ats and freshwater marshes extend several kilometers inland. Littoral drift currents transport sand-size sediments from the Portuguese coast to the Spanish nearshore zone, determining the form of each coastal stretch (C.E.E.P.Y.C., 1979; Cuena, 1991).

\section{Material and methods}

\subsection{Geomorphology}

In a prior step, the geomorphology of the Don ana National Park was mapped from 1:33000 aerial photographs, taken in 1956. The initial cartography of the £uvial elements (i.e., levees, £uvial channels) and marine forms (i.e., spits) was partly modiced with direct observation in the celd, owing to a modest topographic gradient of about $1 \mathrm{~m}$ dijerence in height. Finally, a more restricted area (Fig. 1: Vetalengua-Las Nuevas) was selected for coring, containing the main geomorphological features of the estuary. Four cores $\left(A^{\wedge} \mathrm{D}\right)$ were collected with a $20 \mathrm{~mm}$ diameter vibracore reaching upto $1 \mathrm{~m}$ depth. The lithology 
A

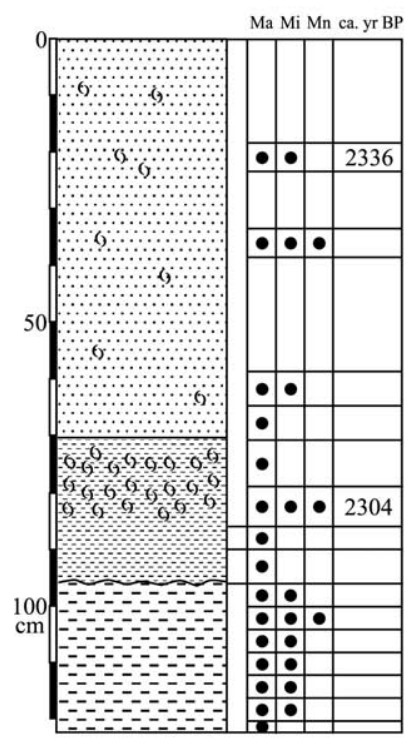

B

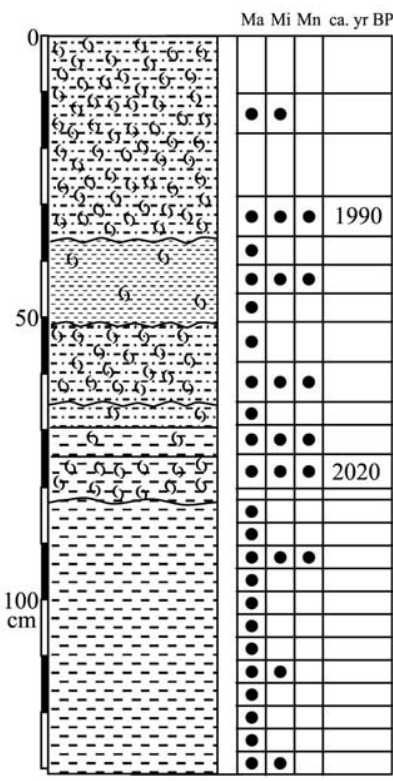

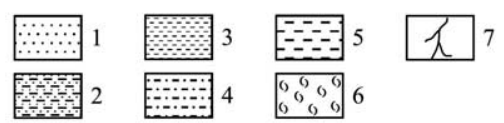

C

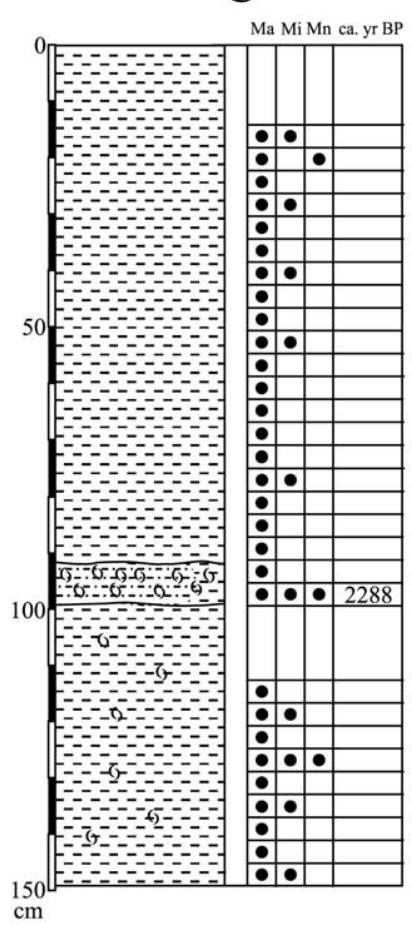

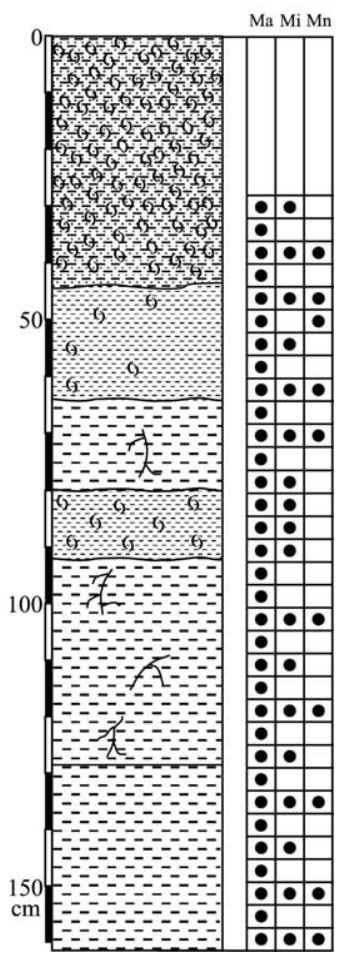

Fig. 2. Lithological features of the cores, including the situation of the samples taken and the type of studies realized in each sample. Age: highest probability age in cal. yr BP. Lithological key: 1: sands; 2: silty sands; $3:$ silts; 4: silty clays; 5: clays; 6: accumulations of invertebrate shells; 7: roots. Ma : macrofauna; Mi : microfauna; Mn : mineralogy.

of each core was described during keld sampling (Fig. 2).

\subsection{Mineralogy}

The mineralogy of 22 samples was studied by $\mathrm{X}$-ray di iraction applied to the whole sample (Fig. 3). The equipment used was a Philips PW $1130 / 90$, with an automatic slit, using KK radiation of $\mathrm{Cu}$ and a Ni $\notin$ lter at $20 \mathrm{~mA}$ and $40 \mathrm{kV}$. The $62 \mathrm{Wm}$ fraction was separated by a standard sedimentation method (Barahona, 1974). Before the separation, carbonates were eliminated using $0.6 \mathrm{~N}$ acetic acid.

Three groups of minerals may be di $i_{j}$ erentiated in the enal results, according to the origin: (a) detritic minerals (quartz, calcite, feldspars, dolomite, aragonite) ; (b) decantation minerals (phyl- losilicates); and (c) evaporative, synsedimentary minerals (halite).

\subsection{Paleontology}

One hundred samples were obtained for macrofossil analysis (Fig. 4). Samples were collected and prepared by washing the bulk sediment $\left(12 \mathrm{~cm}^{3}\right)$ through a $1-\mathrm{mm}$ sieve. Bivalves and gastropods were identiced to the species level and counted to study the semi-quantitative distribution in each core. In relation to the reduced amount of sediment studied, the abundance of a species in each sample was described as follows: fragments, rare (one specimen), frequent $\left(2^{\wedge} 5\right.$ specimens $)$ and abundant ( $\mathbf{S} 5$ specimens).

Forty-seven samples of approximately $15 \mathrm{~g}$ were taken for microfossil analysis, which are se- 

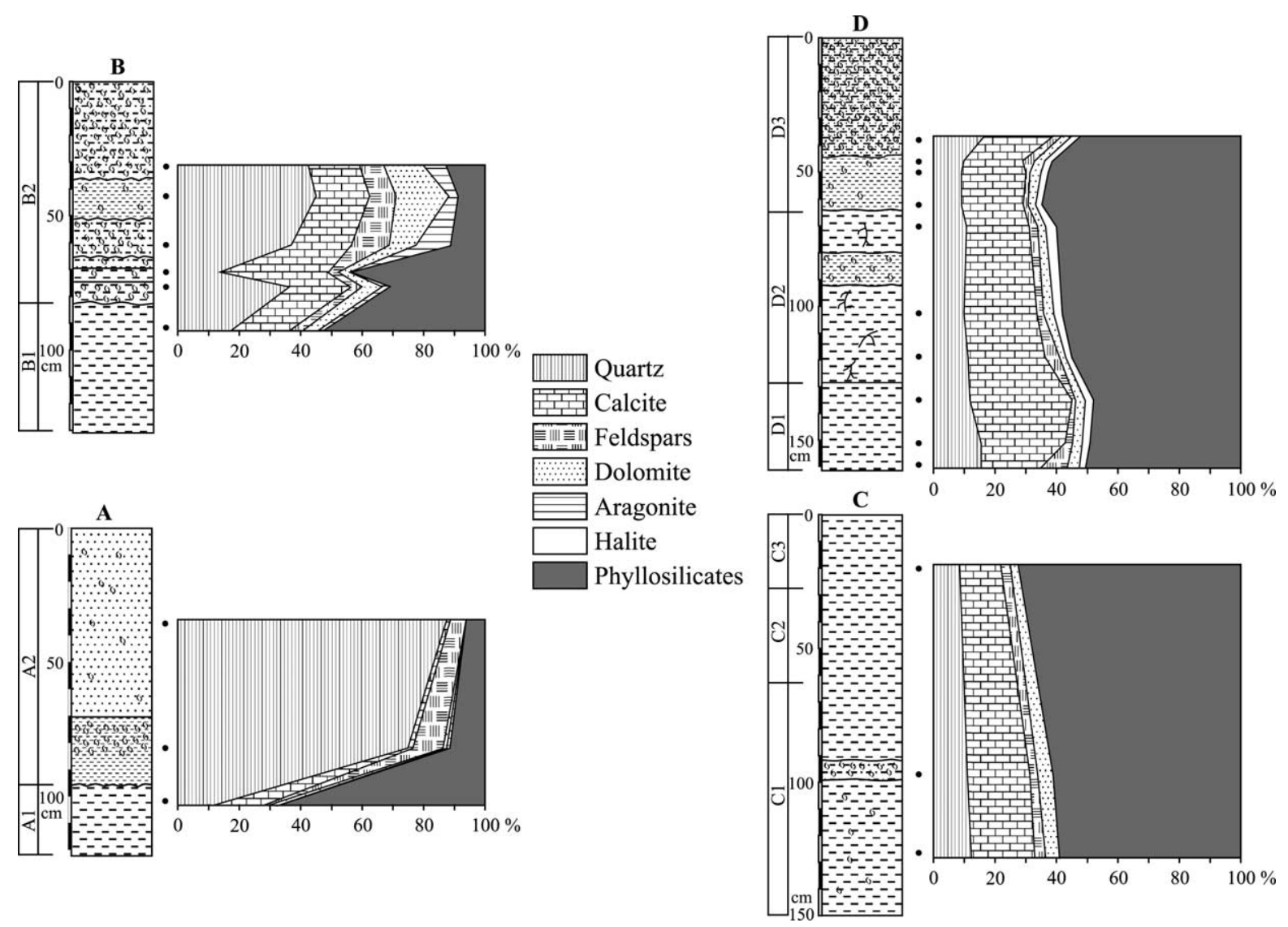

Fig. 3. Mineralogical record of the cores.

lected according to the main sedimentary changes observed in the cores (Fig. 5). These samples were washed through a $63-\mathrm{Wm}$ sieve to remove the mud fraction and then dried. If possible, more than 300 ostracode valves and carapaces from each sample were picked onto faunal microscope slides. Both the abundance of each species and the number of individuals per gram in each sample were calculated (Fig. 5). A total list of recorded macroand microfossils in the cores is given in the Appendix.

\subsection{Dating}

Five datings were carried out at the Beta Analytic Laboratory (Miami, FL, USA) and the Centro di Studio per il Quaternario e l'Evoluzione Ambientale del CNR (Rome, Italy) by radiocar- bon methods applied to mollusc shells (Table 1). Data were calibrated using CALIB version 4.3 (Stuiver and Reimer, 1993) and the Stuiver et al. (1998) calibration dataset. The enal results correspond to calibrated ages (cal.) using 2c intervals, with a reservoir correction (3440 Q $85 \mathrm{yr}$ ) as suggested in Lario (1996) and Dabrio et al. (1999, 2000) for this area. Ages discussed below will be expressed as the highest probable age of the $2 \mathrm{c}$ calibrated range (e.g., Van der Kaars et al., 2001)

\section{Results}

4.1. Geomorphology of the Donana National Park

The geomorphological analysis makes it possi- 


\begin{tabular}{lllllllll}
\hline Core & $\begin{array}{l}\text { Depth } \\
(\mathrm{cm})\end{array}$ & Lab. number & Material dated & $\begin{array}{l}\text { Uncorrected age } \\
(\mathrm{yr} \mathrm{BP})\end{array}$ & $\begin{array}{l}\text { Error } \\
(\mathrm{Q} \text { yr })\end{array}$ & $\begin{array}{l}\text { Max. age } \\
(\text { cal. yr BP) }\end{array}$ & $\begin{array}{l}\text { Highest probability age } \\
(\text { cal. yr BP })\end{array}$ & $\begin{array}{l}\text { Min. age } \\
(\mathrm{cal} . \mathrm{yr} \text { BP })\end{array}$ \\
\hline A & 82 & R-2283 & Mollusc & 2171 & 36 & 2511 & 2304 & 2056 \\
A & 20 & B-88016 & Mollusc & 2230 & 60 & 2696 & 2336 & 2108 \\
B & 90 & B-154079 & Mollusc & 1960 & 40 & 2293 & 2020 & 1813 \\
B & 31 & B-154082 & Mollusc & 1940 & 60 & 2294 & 1990 & 1766 \\
C & 95 & B-145203 & Mollusc & 2140 & 70 & 2593 & 2288 & 1975 \\
\hline
\end{tabular}

Laboratory: B: Beta Analytic (Miami, FL, USA); R: Centro di Studio per il Quaternario e l'Evoluzione Ambientale del CNR, Dipartimento Scienze della Terra, Universita La Sapienza (Rome, Italy).

ble to delimit the £uvial levees £anking the river and its former courses, with two main directions (north ${ }^{\wedge}$ south and west ${ }^{\wedge}$ east). These levees have a variable width $\left(300^{\wedge} 1500 \mathrm{~m}\right)$ and length (upto $3^{\wedge}$ $5 \mathrm{~km}$ ), reaching heights of $0.8^{\wedge} 1 \mathrm{~m}$ above the adjacent marshes. Soils are aquic xerochrepts (Clemente et al., 1998), with vegetation composed of Arthrocnemun macrostachyum.

The 'hills' $\left(2^{\wedge} 2.5 \mathrm{~m}\right.$ about the marsh level $)$ are occupied by some levees overlain by characteristic accumulations of bivalves, with a beach ridge morphology (Figs. 1 and 7, F: Las Nuevas). They are elongated $\left(3^{\wedge} 6 \mathrm{~km}\right)$, with a narrow width $\left(20^{\wedge} 30 \mathrm{~m}\right)$ and thickness $\left(0.5^{\wedge} 0.7 \mathrm{~m}\right)$ and can be classiced as cheniers (Otvos and Price, 1979; Augustinus, 1989; Rodr $¥ g u e z-R a m \neq r e z$ et al., 2001). Cores B and D were collected over one of these 'hills' (Las Nuevas).

Depressions (core C) are formed by the active ${ }^{\wedge}$ inactive fuvial channels and other areas conфned by channels or former levees. These areas remain wet during the summer months, containing permanent waters or delimiting temporary ponds from November to June. Vegetation is characterized by the presence of Scirpus lacustris and Scirpus maritimus, living over typic salorthid or aquollic salorthic soils (Clemente et al., 1998).

Finally, the estuary is partly enclosed by two main sandy spits (Fig. 1): Don ana (western bank) and La Algaida (eastern bank). These beds are composed of active dunes disposed in narrow $(6100 \mathrm{~m})$ and elongated $\left(1^{\wedge} 2 \mathrm{~km}\right)$ alignments, with a limited thickness $(61.5 \mathrm{~m})$ in most cases.
4.2. Lithostratigraphic, mineralogical and macrofaunal analysis

\subsubsection{Core A}

The lower $28 \mathrm{~cm}$ of this core are represented by massive, green to grayish clays with scattered fragments of bivalves. The total mineralogy is composed of phyllosilicates $(68 \%)$, calcite $(16 \%)$ and quartz $(12 \%)$. These clays are overlain by a silty bed $(25 \mathrm{~cm}$ thickness) with numerous fragments of bivalves (Cardium edule) and gastropods. The upper $80 \mathrm{~cm}$ are composed of yellow, ene to medium sands very rich in quartz (Fig. 3: $75^{\wedge}$ $88 \%)$, with phyllosilicates $\left(6^{\wedge} 11 \%\right)$ and feldspars $\left(5^{\wedge} 10 \%\right)$ as accessories.

\subsubsection{Core $\mathrm{B}$}

This core can be divided into two lithological intervals. Between 132 and $68 \mathrm{~cm}$ below surface, this core is characterized by a continuous sequence of green-gray silty clays with scarce traces of burrowing organisms. Phyllosilicates $\left(31^{\wedge} 52 \%\right)$ are dominant over quartz $\left(14^{\wedge} 36 \%\right)$ and calcite $\left(19^{\wedge} 35 \%\right)$, with feldspars and dolomite as minor constituents. The limited paleontological record is composed of the pulmonate gastropod Melanopsis and numerous fragments of roots.

The upper zone (68 $\mathrm{cm}$ thickness) is formed by two levels of silty clays (5Y 4/2) enclosing lumachelle accumulations of invertebrate shells. These sediments are rich in quartz $\left(37^{\wedge} 42 \%\right)$, calcite $\left(17^{\wedge}\right.$ $19 \%)$, phyllosilicates $\left(12^{\wedge} 13 \%\right)$, feldspars $\left(8^{\wedge} 13 \%\right)$, dolomite $\left(8^{\wedge} 13 \%\right)$ and aragonite $\left(8^{\wedge} 12 \%\right)$. Macrofauna is strongly dominated by disarticulated 
valves of the bivalve Cardium edule with multiple growth stages $\left(0.25^{\wedge} 2 \mathrm{~cm}\right.$ length $)$ and frequent specimens of Melanopsis (Fig. 4). These species are accompanied by numerous juvenile valves of Venerupis decussatus and, to a lesser extent, by other marine bivalves (i.e., Crassostrea angulata, Donax vittatus, Corbula gibba, Glycymeris glycymeris) and gastropods (Calyptraea chinensis). In addition, the uppermost samples contain both freshwater and pulmonate gastropods (Helix sp., Gyraulus laevis).

A more silty bed $\left(52^{\wedge} 38 \mathrm{~cm}\right.$ below surface $)$ is interbedded between these fossiliferous units, containing frequent shells of bivalves (Cardium edule, Venerupis decussatus). Quartz (45\%) and dolomite $(17 \%)$ are more abundant, whereas aragonite $(3 \%)$ and phyllosilicates $(10 \%)$ decrease.

\subsubsection{Core $\mathrm{C}$}

This core is composed of clays with very limited sand contents (62\%). Color makes it possible to distinguish between a lower layer (color 10YR 5/ 3 ) and an upper zone ( $644 \mathrm{~cm}$ depth; color $5 \mathrm{Y}$ $4 / 2$ ). In the former layer, the phyllosilicate content $\left(58^{\wedge} 62 \%\right)$ increases toward the top, whereas calcite $(621 \%)$ and quartz $\left(11^{\wedge} 13 \%\right)$ decrease in the same direction. Sediments from this bed contain a macrofauna composed of bivalves (Venerupis decussatus, Cardium edule, Crassostrea angulata), with a frequent occurrence of echinoderm spines. A silty layer with numerous mollusc shells was observed at $102^{\wedge} 94 \mathrm{~cm}$ below surface, with similar mineralogy. Crassostrea angulata and fragments of Venerupis decussatus are very abundant ( $\mathbf{s} 20 \%$ dry weight) in this layer.

In the upper part of this core, there is a clear enrichment in phyllosilicates $(72 \%)$, with lesser quantities of quartz $(8 \%)$ and calcite $(14 \%)$. Macrofauna is absent or very scarce in most samples.

\subsubsection{Core D}

This core presents a lower interval $\left(162^{\wedge} 129 \mathrm{~cm}\right.$ below surface) characterized by massive, blue clays with very sparse macrofauna. These $\notin$ ne sediments are composed of quartz $\left(13^{\wedge} 16 \%\right)$, calcite $\left(19^{\wedge} 32 \%\right)$ and phyllosilicates $\left(47^{\wedge} 51 \%\right)$. Over this zone, very similar sediments $\left(129^{\wedge} 63 \mathrm{~cm}\right.$ below surface) present abundant fragments of pha- nerogams, numerous roots and an increasing phyllosilicate contents $\left(55^{\wedge} 61 \%\right)$. This homogeneous lithology is only interrupted at a core depth of $91^{\wedge} 79 \mathrm{~cm}$ by a silty level with scattered fragments of bivalves (Cardium edule).

The third interval $\left(63^{\wedge} 43 \mathrm{~cm}\right.$ below surface) is represented by silts with frequent shells of Cardium edule, Spisula solida and Rissoa sp. Phyllosilicates are very abundant $\left(60^{\wedge} 65 \%\right)$, with the quartz $\left(9^{\wedge} 10 \%\right)$ and calcite $\left(19^{\wedge} 21 \%\right)$ contents nearly constant. The upper $43 \mathrm{~cm}$ present a yellow, sandy body (18\% quartz) with abundant and well-preserved molluscs (mainly Cardium edule). This macrofauna was disposed in massive beds or in plane-parallel strata.

\subsection{Microfossil analysis}

\subsubsection{Autoecological groups of ostracodes}

Three main groups of ostracodes may be distinguished (Fig. 5), each one constituted by species with analogous ecology (Carbonel, 1980; Clave et al., 2001): (a) fresh to low brackish water assemblage : Cyclocypris laevis, Cypridopsis vidua, Cypris bispinosa, Herpetocypris chevreuxi, Ilyocypris gibba and Cyprinotus salinus; (b) high brackish water assemblage: Cyprideis torosa (smooth ornamentation), Leptocythere castanea and Loxoconcha elliptica; and (c) coastal, marine assemblage : Carinocythereis whitei, Neocytherideis subulata, Palmoconcha guttata, Palmoconcha laevata, Pontocythere elongata, Semicytherura $\mathrm{sp}$. and Urocythereis oblonga.

\subsubsection{Zonation of the cores}

4.3.2.1. Core A. The ostracode record makes it possible to delimit two zones in this core. In the lower $28 \mathrm{~cm}$ (Zone A1), the very scarce ostracode valves observed (Cyprideis torosa, Leptocythere castanea, Loxoconcha elliptica) are found together with numerous estuarine foraminifers (Ammonia tepida, Astrononion stelligerum) and some marine specimens, both benthic (Uvigerina peregrina, Globobulimina auriculata) and planktonic (Orbulina universa, Globigerina bulloides). Towards the top, this assemblage coincides with the presence of numerous plant fragments. Zone A2 (upper $96 \mathrm{~cm}$ ) 
is characterized by the absence of both foraminifers and ostracodes.

4.3.2.2. Core B. Two zones may be distinguished in this core. In the lowermost samples (Zone B1: 132^110 $\mathrm{cm}$ below surface), ostracodes are poorly represented by some juvenile instars of Leptocythere castanea and Urocythereis oblonga (synonym of Urocythereis britannica). In the upper samples (Zone B2), the number of individuals per gram is very low ( 613 ), Cyprideis torosa being the most representative species ( $S 89 \%$ of the valves). Loxoconcha elliptica and Pontocythere elongata are well represented through these samples.

4.3.2.3. Core C. The ostracode content and composition delimit three zones in core $\mathrm{C}$. Zone C1 $\left(148^{\wedge} 72 \mathrm{~cm}\right.$ below surface) is characterized by a very high density ( $\mathbf{S} 500$ individuals $/ g$ ) with a maximum at $3124 \mathrm{~cm}$ depth. The ostracode assemblage is composed of Cyprideis torosa, Leptocythere castanea and Loxoconcha elliptica (Fig. 5), Cytherois $\phi$ scheri being the main secondary species. Other species (Palmoconcha laevata, Semicytherura spp., Neocytherideis subulata, Pontocythere elongata) are only represented by juvenile instars in some isolated samples. In the upper part of this zone $\left(100^{\wedge} 90 \mathrm{~cm}\right.$ below surface), the ostracode density decreases $\left(200^{\wedge} 250\right.$ individuals/ $\mathrm{g})$, coinciding with the presence of frequent bivalve shells.

Zone $\mathrm{C} 2\left(72^{\wedge} 32 \mathrm{~cm}\right.$ below surface $)$ presents a marked dropin the ostracode density ( 635 individuals $/ g$ ), with a progressive disappearance of the latter assemblage and the appearance of new species (Cyprinotus salinus, Cypridopsis vidua). This zone is also evidenced by the appearance and increasing abundance of calcareous gyrogonites belonging to the genus Chara, a charophyte alga (Class Charophyceae).

Zone $\mathrm{C} 3\left(0^{\wedge} 32 \mathrm{~cm}\right.$ depth $)$ is dominated by Cyprinotus salinus, with minor contributions of Ilyocypris gibba, Herpetocypris chevreuxi, Cypridopsis vidua, Cypris bispinosa and scarce, poorly mineralized specimens of Cyprideis torosa (instars A-3 to A-1). Density is di/cult to estimate, with abundant fragmented valves of these weakly calciced species. Charophytes and fragments of stems and roots are very numerous.

\subsubsection{Core D. Ostracode analysis enables} three zones to be established in this core. Zone D1 $\left(162^{\wedge} 129 \mathrm{~cm}\right.$ below surface $)$ presents a rich ostracode assemblage dominated by Cyprideis torosa and Loxoconcha elliptica, with Leptocythere castanea and Leptocythere tenera as additional species. In this zone, the number of ostracodes decreases towards the top. A second zone (D2: $129^{\wedge} 63 \mathrm{~cm}$ below surface) is decned by the absence of ostracodes or the presence of sparse specimens ( 62 individuals/g) belonging to very juvenile individuals (instars A-4 to A-6) of Cyprideis torosa and/or Loxoconcha elliptica. This zone includes a diversiced assemblage (16 species) at a core depth of $91^{\wedge} 79 \mathrm{~cm}$, with abundant valves of Cyprideis torosa, Palmoconcha laevata and Loxoconcha elliptica. In Zone D3 (upper $63 \mathrm{~cm}$ ), both the ostracode diversity and density increase towards the top. Cyprideis torosa, Palmoconcha laevata and Pontocythere elongata are the main species in this zone.

\subsection{Radiometric dating}

In core $\mathrm{A}$, two dates were obtained on the estuarine bivalve Cardium edule, indicating the calibrated age of Vetalengua : 2511^2304^2056 yr BP (82 cm depth) and $2696^{\wedge} 2336^{\wedge} 2108$ yr BP (20 cm depth). Another two samples were dated in core $B$, collected in the chenier of Las Nuevas : $2293^{\wedge}$ $2020^{\wedge} 1813$ yr BP $\left(90 \mathrm{~cm}\right.$ depth) and $2294^{\wedge} 1990^{\wedge}$ $1766 \mathrm{yr}$ BP (31 cm depth). These data may indicate some reworking of the upper shells collected in either cores or, more probably, the deposit of the whole cheniers in the same events.

An additional, lateral sampling makes it possible to correlate the chenier of Las Nuevas with

Fig. 4. Distribution of macrofossils in the cores. Abundance: rare (one specimen); frequent ( $2^{\wedge} 5$ specimens); abundant ( $\mathbf{S} 5$ specimens). 

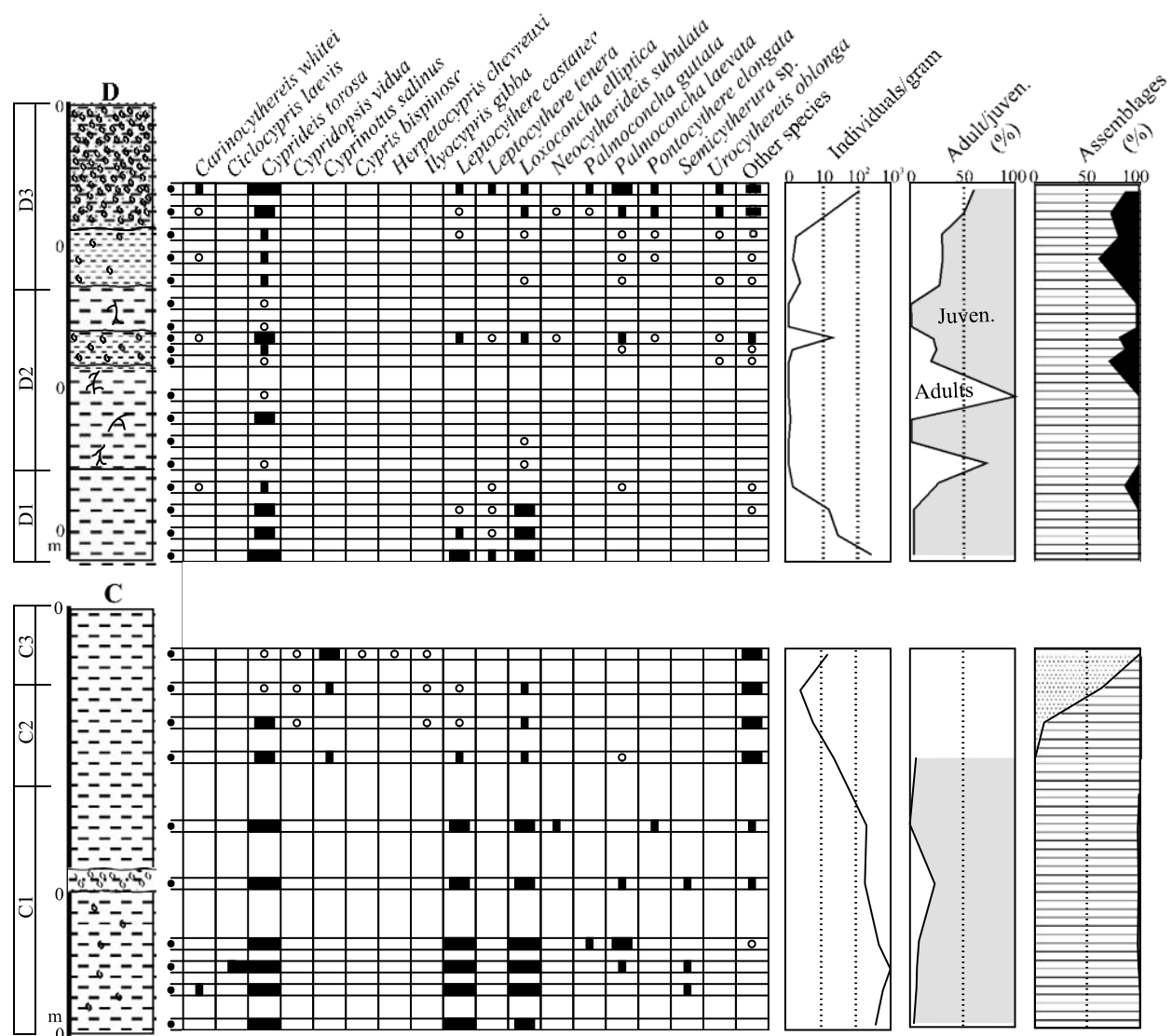

B
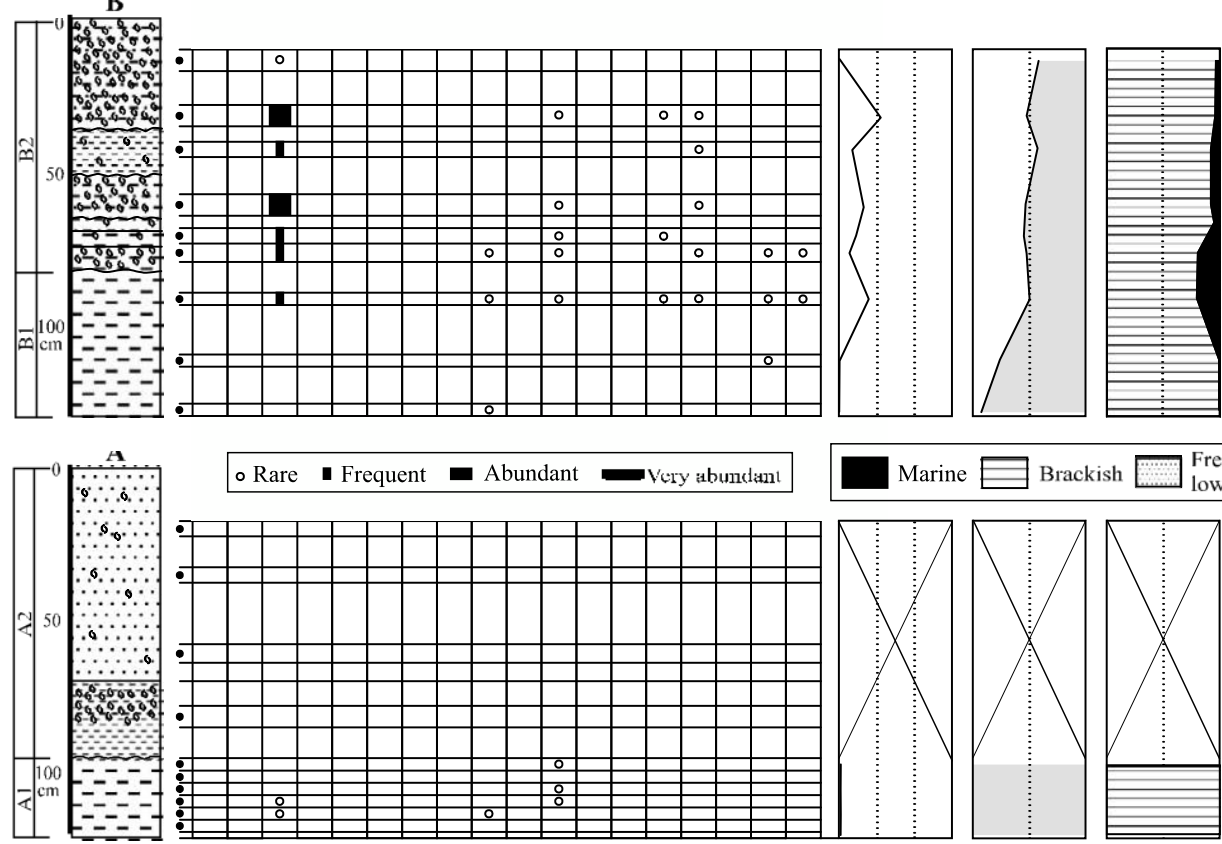

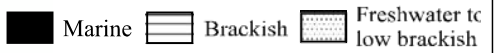
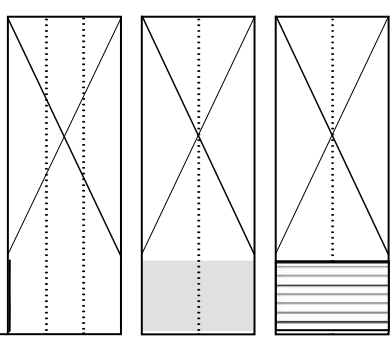
the upper $43 \mathrm{~cm}$ of core D. Finally, an additional sample was dated in core C $\left(2593^{\wedge} 2288^{\wedge} 1975 \mathrm{yr}\right.$ BP; $95 \mathrm{~cm}$ depth), very close to the radiocarbon age of Vetalengua.

\section{Paleoenvironmental reconstruction ofthe cores}

Four phases may be separated in the environmental sequence of the cores collected.

\subsection{Phase $1\left(\mathbf{s} 2400^{\wedge} 2500\right.$ cal. yr BP $)$}

The lower limit of this phase is not observed in the cores studied, whereas the upper limit coincides with the $\phi$ rst level of bivalve accumulation, which presents similar ages in cores $\mathrm{A}$ and $\mathrm{C}$ (highest probability between 2288 and $2336 \mathrm{yr}$ BP) and may be laterally correlated with core D. In core A, the ostracode and foraminiferal assemblages (mainly Ammonia tepida, Haynesina germanica, Trochammina in£ata, Quinqueloculina seminulum) of Zone A1 evidence a mud£at deposit (Cearreta, 1998), with introduction of marine, planktonic species (Orbulina, Globigerina) during the tidal fux. Near the top $\left(105^{\wedge} 96 \mathrm{~cm}\right.$ below surface), the presence of frequent phanerogam fragments and the reduced microfauna indicate the transition towards a vegetated, supratidal salt marsh (Fig. 6). In this environment, ostracodes are usually absent (Penney, 1985).

During this phase, the rich ostracode assemblage (Cyprideis torosa, Loxoconcha elliptica, Leptocythere castanea) collected in Zones $\mathrm{C} 1$ (lower part) and D1 indicates the presence of a brackish lagoon (salinity $625^{\wedge} 30 x$ ) in the southwestern sector of the Don ana National Park. These species characterize the inner, shallow areas $(61 \mathrm{~m}$ depth) of recent lagoons with marine connection, located near the lagoon shore and close to a river mouth (Athersuch et al., 1989; Marocco et al., 1996; Montenegro and Pugliese, 1996; Ruiz et al., 2000a).

The $\notin$ ne to very $\notin$ ne sediments observed indi- cate a calm environment dominated by suspension processes, with $\mathrm{NaCl}$-rich waters as evidenced by the smooth-shelled Cyprideis (Anadon et al., 1986). The marine infuence was strong, with transport of marine bivalves (mainly Venerupis decussatus) and instars of ostracodes (Palmoconcha laevata, Palmoconcha guttata or Semicytherura spp.) towards the inner lagoon during the tidal fux or by storms. These species are frequent in the recent marine assemblages (620 m depth) of the southwestern Spanish Atlantic coasts (Perez Quintero, 1989; Ruiz et al., 1997).

\subsection{Phase $2\left(\mathrm{~V} 2400^{\wedge} 2200\right.$ cal. yr BP)}

In the lower part of Zone A2, the occurrence of a $\not$ ne level of bivalves, including estuarine (Cardium edule) and marine (Venerupis decussatus, Solen marginatus) species, may be indicative of a storm deposit (Regnauld, 1999). This level lies unconformably over the marsh deposits and is followed vertically by eolian, $k$ ne to medium sands with very high quartz contents ( $\mathbf{5} 75 \%$ ). This bed is perpendicular to the Don ana spit and may represent a breakthrough of this spit owing to a high-energy event (strong storm ?, tsunami ?). This area will remain emerged in the successive phases.

This rupture permits the introduction of both marine macrofauna (Crassostrea angulata, Venerupis decussatus, fragments of scaphopods, bryozoans and sponges) and microfauna (Basslerites berchoni, Carinocythereis whitei, Semicytherura sp.) towards the inner lagoon. These reworked faunas are accumulated in core $\mathrm{C}$ (middle part of Zone $\mathrm{C} 1$ ) and, to a lesser extent, in core D (boundary between Zones D1 and D2).

\subsection{Phase $3\left(V^{2} 200^{\wedge} 2050\right.$ cal. yr BP)}

The intertidal $\wedge^{\wedge}$ supratidal areas of this lagoon are represented in Zone B1, with scarce ostracods, presence of pulmonate gastropods, rhyzolites and the absence of marine shells. Similar features were

Fig. 5. Ostracode distribution in the cores collected. Abundance: rare ( 610 specimens); frequent $\left(11^{\wedge} 100\right.$ specimens $)$; abundant

(101^1000 specimens); very abundant ( s 1001 specimens). 


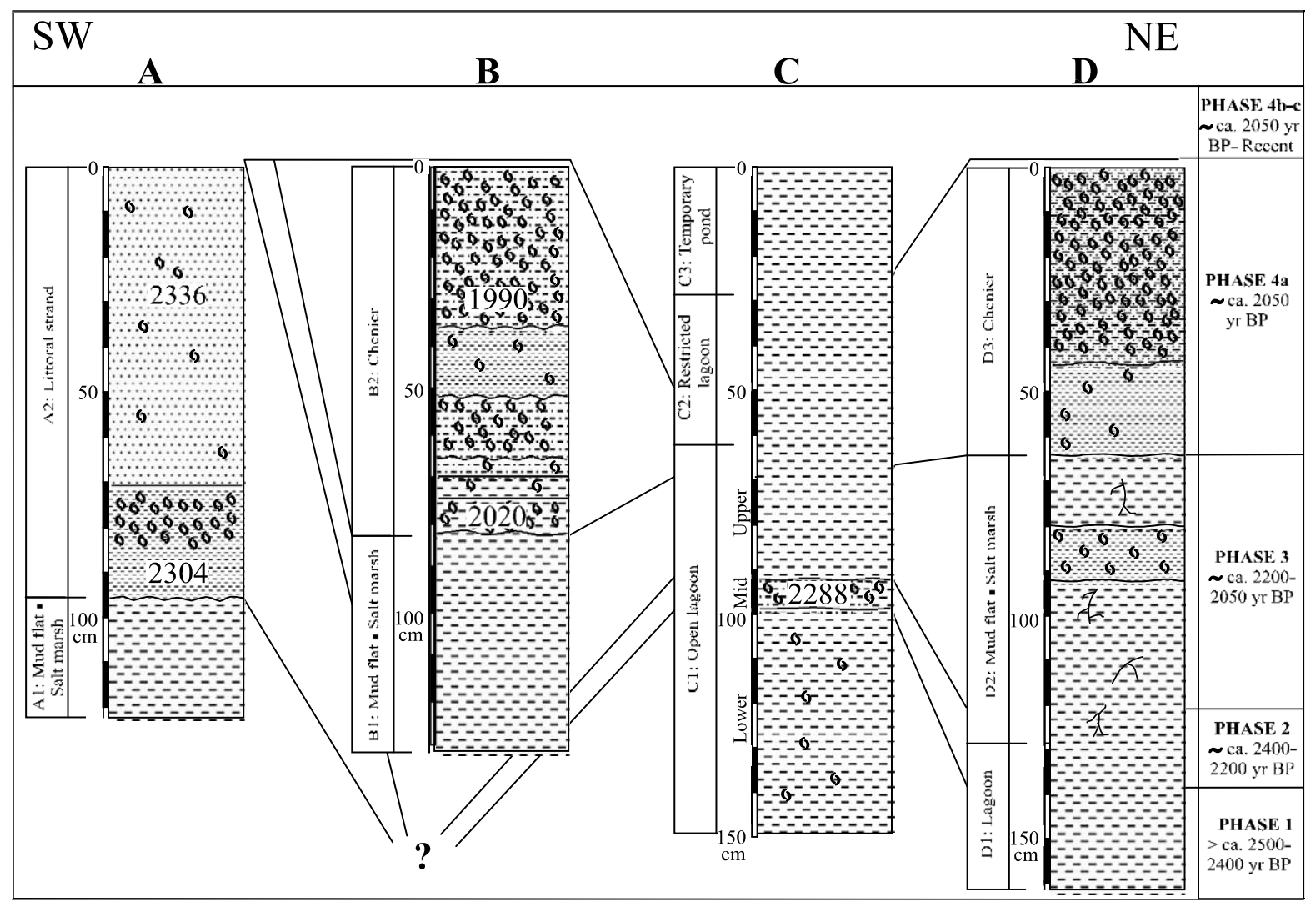

Fig. 6. Paleoenvironmental reconstruction and correlation of the cores, including the mean calibrated ages obtained.

found in Zone D2, indicating the emersion of the eastern sector during this phase. In this zone, the total mineralogy of the bottom lagoon and the intertidal areas is very similar (phyllosilicatesE calcite $\mathbf{s}$ quartz).

The immerged area (upper part of Zone C1) presents a marked reduction of the ostracode density ( $\mathbf{S} 500$ to $200^{\wedge} 250$ individuals/g), disappearance or diminution of species adapted to quiet hydrodynamic conditions (i.e., Cytherois \&scheri; Ruiz et al., 2000b) and the introduction of small marine ostracodes (Neocytherideis subulata, Semicytherura incongruens) and molluscs.

\subsection{Phase 4 (V2050 cal. yr $\mathrm{BP}^{\wedge}$ Recent)}

This phase may be divided into three episodes. Cheniers (Zones B2 and D3; V2000 cal. ${ }^{14} \mathrm{C}$ yr $\mathrm{BP})$ are the most characteristic feature of the $\mathrm{erst}$ period (Fig. 6). These deposits are produced due to storms, sea-level changes, tidal £uxes, drift currents or biological crises (Augustinus, 1989), but the enal result is the accumulation of massive beds $\left(0.4^{\wedge} 1.5 \mathrm{~m}\right.$ thickness $)$ of estuarine macrofossils over the intertidal ${ }^{\wedge}$ supratidal areas of the lagoon (boundary between Zones $\mathrm{C} 1$ and $\mathrm{C} 2$ ), with some additional marine specimens. The estuarine association is composed of the bivalve Cardium edule and numerous ostracode valves (Cyprideis torosa, Loxoconcha elliptica). In addition, some larger marine species ( $\mathbf{S} 1 \mathrm{~cm}$ length) of bivalves (Venerupis decussatus, Corbula gibba, Donax vittatus, Crassostrea angulata) and gastropods (Rissoa sp., Calyptraea chinensis) were transported, probably in saltation, from the coastal areas during these events (storms?, tsunami ?, exceptionally high tides?), together with the suspension transport of juvenile instars of some ostracode species 
(Palmoconcha laevata, Pontocythere elongata, Urocythereis oblonga), very frequent in these shallow zones (Ruiz et al., 1997).

The second episode (Zone C2) has been dijerentiated according to the diminution in the marine macrofauna (Fig. 4: Venerupis decussatus, Rissoa sp., spines of echinoderms) and the ostracode density. In this group, Cyprideis torosa is replaced by freshwater species, such as Cyprinotus salinus or Cypridopsis vidua (Bodergat, 1983; Bronshtein, 1988). In addition, the charophytes increase progressively towards the top of the core. These changes are interpreted as a more restricted tidal fux in this area, decreasing the marine inputs. In the area studied, the consequence is the partial isolation of a local depression between the chenier of Las Nuevas and the new, youngest levees, growing towards the south. Both the diminution of the marine infuence and the domain of the fuvial component cause an environmental crisis in the estuarine assemblages.

The \&nal episode (Zone C3) marks the de $\phi$ nitive establishment of freshwater conditions. Cyprinotus salinus becomes the main ostracode species, with Ilyocypris gibba, Cypridopsis vidua and Herpetocypris chevreuxi as additional forms. The charophyte gyrogonites (mainly the genus Chara) are very abundant in these upper sediments. Today, this ostracode ${ }^{\wedge}$ charophyte assemblage is found in the temporary/permanent ponds (locally known as 'lucios') of the Don ana National Park (Ruiz et al., 1996). These ponds are small, shallow ( $61 \mathrm{~m}$ depth) waters with alkaline $\mathrm{pH}\left(7^{\wedge} 10.6\right)$ and large water temperature variations $\left(8^{\wedge} 10 \ddagger \mathrm{C}\right.$ in December ${ }^{\wedge}$ January and $25^{\wedge} 30 \ddagger \mathrm{C}$ during the summer) (Serrano and Toja, 1995).

\section{Late Holocene evolution ofthe Roman Lacus Ligustinus}

In the last 2500 years, the paleoenvironmental changes of the southwestern Guadalquivir estuary have been registered both in the dijerent geomorphological elements and in the succession of biological assemblages observed in the cores studied. Before $2400^{\wedge} 2500$ cal. yr BP, the inner estuary was formed by a wide, relatively quiet lagoon
(Fig. 7A: phase 1 in this work), with a clayey bottom colonized by numerous populations of the bivalve Cardium edule and an ostracode assemblage composed of Cyprideis torosa, Loxoconcha elliptica and Leptocythere castanea. The marine infuence was strong, with introduction of shallow, coastal bivalves (Venerupis decussatus) and ostracodes (Palmoconcha guttata, Palmoconcha laevata) during the tidal fuxes. The Don ana spit was shorter and narrower than at present, with a good development of dunes (Rodr $¥ g u e z-$ Ramłrez et al., 1996). Further north, this coastal lagoon was limited by emerged salt marshes, with an extensive development of £uvial levees, similar to digitate deltas (Rodrłguez-Ram中rez et al., 1997). This lagoon may be assimilated to the Lacus Ligustinus described by the chroniclers Strabo and Mela.

Between V2400 and 2200 cal. yr BP, an erosive phase (Fig. 7B: phase 2) occurred in this area. A high-energy event (storm ?, tsunami ?) broke the Don ana spit and opened a new communication with the sea, with generation of washover fan deposits represented in Zone A2 (Vetalengua). This event is also recorded by an erosive stepin the dijerent beach ridges of the Don ana spit (Rodr\$guez-Ram中rez, 1996，1998). In the inner lagoon, this opening caused the introduction of reworked, marine assemblages (middle part of Zone $\mathrm{C} 1$ ). This phase coincides with the enal stage of an erosive phase decned by Zazo et al. (1994) and the presence of tsunami-induced deposits in the southwestern Spanish littoral (Luque et al., 2001; Lario et al., 2001, 2002).

In a third phase (Fig. 7C: V2200^2050 cal. yr $\mathrm{BP})$, the estuarine inclling was the main feature and the new, western marine connection tends to disappear, in relation with the progradation of the Don ana spit (Rodrłguez-Ramłrez, 1996). The limited supply of marine waters entered the area in the eastern outlet, with a decreasing salinity in the inner lagoon. In this area, the development of £uvial levees originated the emersion of new areas, with an additional reduction of the marine infuence. These new conditions caused a biological crisis in the estuarine assemblages, with a prominent reduction of the ostracode density.

This crisis increased during a later, unstable 

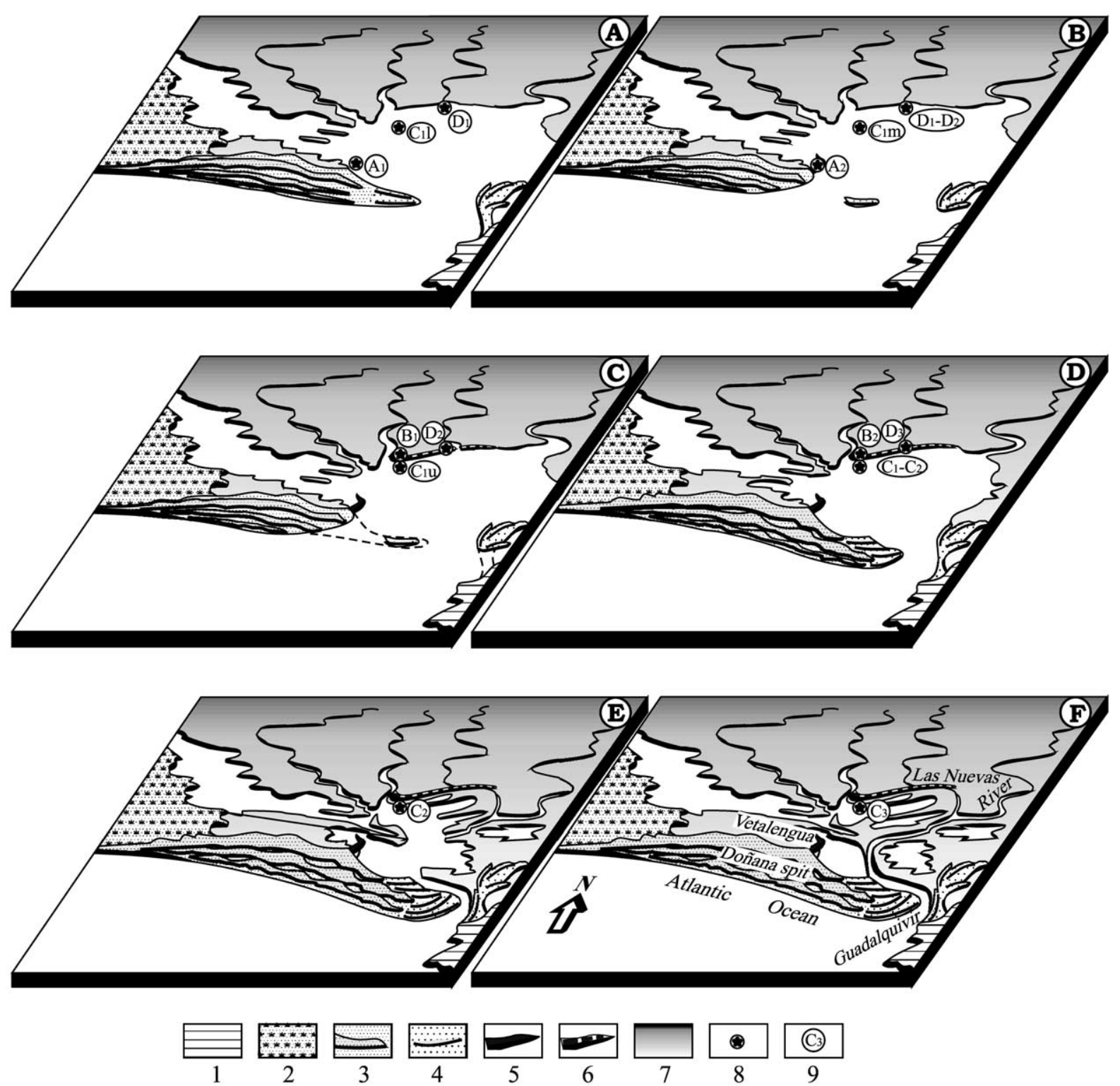

Fig. 7. Late Holocene evolution of the southwestern Don ana National Park. A: Phase 1; B: Phase 2; C: Phase 3; D: Phase 4a; E: Phase 4b; F: Phase 4c^Recent. Key: 1: Plio^Pleistocene substratum; 2: stabilized eolian sands; 3: active eolian sands with dunes (gray); 4: littoral spits (ridges in gray); 5: littoral ridge of Vetalengua ; 6: chenier of Las Nuevas; 7: marshes (and levees);

8 : location of the cores; 9: microfossil zones ( $\mathrm{u}:$ upper ; $\mathrm{m}:$ middle ; 1 : lower).

period (Fig. 7D: V2050 cal. yr BP). The clayey bottom of the Lacus Ligustinus was eroded by storms or other high-energy events, with accumulation of dijerent bodies of mollusc shells (cheniers) over the previous emerged levees (phase $4 a$ ). Moreover, some marine species were introduced into the lagoon via a single mouth, being deposited in the eastern part of these cheniers (upper part of the core D).

In the last two periods of this phase (Fig. $7 \mathrm{E}, \mathrm{F}$ ), the growth of fuvial levees and the estuarine inclling caused the cnal disappearance of the 
Lacus Ligustinus. Some depressions are isolated between the new levees and cheniers, being periodically fooded by freshwater and/or tidal inputs. The clayey bottom of these 'lucios' is colonized by charophytes, one of the main foods for the numerous ostracode assemblages present, with characteristic, weakly calciced carapaces (upper part of core C). Today, these isolated areas are very common in this sector of the Don ana National Park (Serrano and Toja, 1995).

\section{Conclusions}

A Late Holocene evolution of the southwestern Don ana National park is proposed, based on the multidisciplinary analysis (texture, color, geomorphology, paleontology, mineralogy, dating) of the sediments present in four drill cores collected. This study makes it possible to delimit the geological features of the dijerent paleoenvironments deduced: (a) open lagoon, with numerous bivalves (Cardium edule) and ostracodes (Cyprideis torosa, Loxoconcha elliptica, Leptocythere castanea) living in silty^clayey bottom sediments; (b) restricted lagoon, with a lower number of individuals of the same associations and the appearance of new, low brackish species; (c) temporary pond, with freshwater to low brackish ostracodes (Cyprinotus salinus, Cyclocypris laevis, Ilyocypris gibba) and charophytes; (d) salt $\operatorname{marsh}^{\wedge}$ mud£at, with numerous stems and roots and scarce microfauna; and (e) littoral strand, with sandy sediments originated by the erosion of littoral spits during high-energy events.

In the last 2500 years, four phases have been distinguished, with a progressive estuarine inclling conditioned by the growth of £uvial levees and the progradation of the Don ana spit towards the east. This inclling was periodically interrupted by high-energy events, causing the breakthrough of the Don ana spit and the biological crisis of the estuarine faunas. This crisis induced a strong reduction of the estuarine assemblages (ostracodes and bivalves), with introduction of reworked marine faunas towards the inner estuary. Finally, the studied area is isolated as a temporary pond.

This study may present several practical appli- cations. The correlation of this evolution with historical data makes it possible to delimit the evolutionary history of the Lacus Ligustinus, an old lagoon cited by several Roman and Spanish chroniclers. In addition, this integrated study presents an adequate geological explanation for the recent geomorphological features observed in this UNESCO-MAB Reserve, known worldwide for its biological diversity.

\section{Acknowledgements}

We thank Miguel Casalvãzquez for assistance in the laboratory procedures. We thank P. Carbonel and P.G.E.F. Augustinus for the critical reading of this report. This work was funded by two Spanish DGYCIT Projects (AMB99-0226C03-03 and BTE-2000-1153) and three Research Groups of the Andalusia Board (RNM-135, RNM-238 and RNM-293). This paper is a contribution to the IGCP 396 and 437.

Appendix. Macrofossils and microfossils collected in the Don ana cores

Bivalvia
Acanthocardia tuberculata
Anomia ephippium
Cardium edule
Corbula gibba
Crassostrea angulata
Donax vittatus
Pandora albida
Spisula solida
Venerupis decussatus
Gastropoda
Calyptraea chinensis
Cochlicella barbara
Gyraulus laevis
Helix sp.
Melanopsis sp.
Rissoa sp.
Rumina decollata
Other macrofossils
Scaphopoda
Echinodermata (spines)


Ostracoda

Acanthocythereis sp.

Basslerites berchoni

Carinocythereis whitei

Ciclocypris laevis

Cyprideis torosa

Cypridopsis vidua

Cyprinotus salinus

Cypris bispinosa

Cytherois \&scheri

Herpetocypris chevreuxi

Ilyocypris gibba

Leptocythere castanea

Leptocythere fabaeformis

Leptocythere porcellanea

Loxoconcha elliptica

Loxoconcha rhomboidea

Neocytherides subulata

Palmoconcha guttata

Palmoconcha laevata

Pontocythere elongata

Semicytherura incongruens

Semicytherura sp.

Triebelina raripila

Urocythereis oblonga (=U. britannica)

Xestoleberis communis

Foraminifera (main species)

Benthic

Ammonia beccarii

Ammonia tepida

Astrononion stelligerum

Elphidium crispum

Globobulimina auriculata

Haynesina germanica

Quinqueloculina seminulum

Uvigerina peregrina

Planktonic

Globigerina bulloides

Orbulina universa

Other microfossils

Gyrogonites of Charophyta (mainly Chara spp.)

\section{References}

Albani, A., Favero, V., Serandrei, R., 1995. Condizioni paleoambientali nel sottosuolo di Venezia: la chiesa di S. Lorenzo. Rapp. Ist. Veneziano Sci. Lett. Arti 12, $155^{\wedge} 182$.
Albertotanza, L., Serandrei, R., Favero, V., 1977. I sedimenti olocenici della laguna di Venezia (Bacino Settentrionale). Boll. Soc. Geol. Ital. 96, 243^269.

Anadø̋n, P., De Deccker, P., Juliă, R., 1986. The Pleistocene lake deposits of the NE Baza Basin (Spain): salinity varia-tions and ostracod succession. Hydrobiologia 143 , $199^{\wedge}$

208.

Angliano, R., Anastasio, G., Improta, S., Peresani, M., Ravazzi, R., 2000. A new late glacial to early Holocene palaeobotanical and archaeological record in the Eastern Pre-Alps: the Palughetto basin (Cansiglio Plateau, Italy). J. Quat. Sci. $15,789^{\wedge} 803$.

Athersuch, J., Horne, D.J., Whittaker, J.E., 1989. Marine and Brackish Water Ostracods. Brill, Leiden.

Augustinus, P.G.E.F., 1989. Cheniers and chenier plain: A general introduction. Mar. Geol. 90, 219^229.

Barahona, E., 1974. Arcillas de ladrillerła de la provincia de Granada: evaluaciőn de algunos ensayos de materias pri- mas. Ph.D. Thesis, Granada University, Granada.

Bodergat, A.M., 1983. Les Ostracodes, texmoins de leur environnement: approche chimique et ecologie en milieu lagunaire et oceanique. Thése d'Etat, Lyon University, Lyon.

Borja, F., Zazo, C., Dabrio, C.J., Dłaz del Olmo, F., Goy, J.L., Lario, J., 1999. Holocene aeolian phases and human settlements along the Atlantic coast of southern Spain. Holocene 9, 333^339.

Borrego, J., 1992. Sedimentolog $\Varangle$ a del estuario del r $\Varangle$ o Odiel (SW Espan a). Ph.D. Thesis, Seville University, Huelva.

Borrego, J., Morales, J.A., Pendø̄, J.G., 1993. Elementos morfodinamicos responsables de la evoluciőn reciente del estuario bajo del r $¥$ o Guadiana (Huelva). Geogaceta 11, $86^{\wedge} 89$.

Borrego, J., Ruiz, F., Gonzălez-Regalado, M.L., Pendø̊n, J.G., Morales, J.A., 1999. The Holocene transgression into the estuarine central basin of the Odiel River mouth (Cadiz Gulf, SW Spain) : lithology and faunal assemblages. Quat. Sci. Rev. 18, $769^{\wedge} 788$.

Bronshtein, Z.S., 1988. Fresh-water Ostracoda. Fauna of the USSR Crustaceans. Amerind Publishing, New Delhi.

Carbonel, P., 1980. Les ostracodes et leur interét dans la def-

inition des écosyste̊mes estuariens et de plateforme continentale. Essais d'application á des domains anciens. Merm. Inst. Geol. Bassin d'Aquitaine 11, 1^350.

Carretero, M.I., Ruiz, F., Rodrłguez-Ramฬrez, A., Cåceres, L., Rodrłguez Vidal, J., Gonzălez-Regalado, M.L., 2002. The use of clay minerals and microfossils in palaeoenvironmental reconstructions: the Holocen litoral strands of Las Nuevas (Don ana Nacional Park, SW Spain). Clay Minerals 37, 93^ 103.

Cearreta, A., 1998. Palaeoenvironmental interpretation of Holocene coastal sequences in the southern Bay of Biscay. Geol. Rundsch. 82, 234^240.

C.E.E.P.Y.C., 1979. Plan de estudio de la dinãmica litoral de la provincia de Huelva. Informe Direcciőn General de Puer- tos y Costas, Ministerio Obras Publicas, Madrid.

Chamley, H., 1989. Clay Sedimentology. Springer Verlag, Berlin. 
Chiverrell, R.C., 2001. A proxy record of late Holocene climate change from May Moss, northeast England. J. Quat. Sci. $16,9^{\wedge} 30$.

Clave, B., Massẽ, L., Carbonel, P., Tastet, J.P., 2001. Holocene coastal changes and in llling of the La Perroche marsh (French Atlantic coast). Oceanol. Acta 24, 377^389.

Clemente, L., Garcła, L.V., Siljestrom, P., 1998. Los Suelos del Parque Nacional de Don ana. O.A. Parques Nacionales, Madrid.

Cuena, G.J., 1991. Proyecto de regeneraciőn de las playas de Isla Cristina. Memoria M.O.P.T., Madrid.

Dabrio, C.J., Zazo, C., Lario, J., Goy, J.L., Sierro, F.J., Borja, F., Gonzålez, J.A., Flores, J.A., 1999. Sequence stratigraphy of Holocene incised valley clls and coastal evolution in the Gulf of Ca diz (southern Spain). Geol. Mijnb. 77, $23^{\wedge} 281$.

Dabrio, C.J., Zazo, C., Lario, J., Goy, J.L., Sierro, F.J., Borja, F., Gonzălez, J.A., Flores, J.A., 2000. Depositional history of estuarine incll during the last postglacial transgression (Gulf of Cadiz, Southern Spain). Mar. Geol. 162, 381^404.

Dalrymple, R.W., Zaitlin, B.A., Boyd, R., 1992. Estuarine facies models : conceptual basis and stratigraphical implica- tions. J. Sediment. Petrol. 62, $1130^{\wedge} 1146$.

Davies, J.L., 1964. A morphogenic approach to world shorelines. Z. Geomorphol. 8, 27^42.

De la Vega, A.C., Keen, D.H., Jones, R.L., Wells, J.M., Smith, D.E., 2000. Mid-Holocene environmental changes in the Bay of Skaill, Mainland Orkney, Scotland : an inte- grated geomorphogical, sedimentological and stratigraphical study. J. Quat. Sci. 15, 509^528.

Edwards, R.J., 2001. Mid- to late Holocene relative sea-level change in Poole Harbour, southern England. J. Quat. Sci.

$16,221^{\wedge} 235$.

Favero, V., Serandrei, R., 1981. Evoluzione paleoambientale della laguna di Venezia nell'area archeologica tra Burano e Canale S. Felice. Lav. Soc. Veneziana Sci. Nat. 6, 119^134.

Favero, V., Heyvaert, F., Serandrei, R., 1995. Motta S. Lor- enzo: evoluzione dell'ambiente in un sito archeologico della laguna di Venezia. Rapp. Ist. Veneziano Sci. Lett. Arti

$183^{\wedge} 218$.

Garcła Bellido, A., 1987. La Espan a del siglo primero de nuestra era (segän P. Mela y C. Plinio). Colecciőn Austral, Es- pasa Calpe.

Gerdes, G., Petselberger, B.E.M., Scholz-Bøttcher, B.M., Streif, H., 2003. The record of climatic change in the geo- logical archives of shallow marine, coastal, and adjacent lowland areas of Northern Germany. Quat. Sci. Rev. 22, $101^{\wedge} 124$.

Goy, J.L., Zazo, C., Dabrio, C.J., Lario, J., Borja, F., Sierro, F.J., Flores, J.A., 1996. Global and regional factors controlling changes of coastlines in southern Iberia (Spain) during the Holocene. Quat. Sci. Rev. 15, 773^780.

Kristensen, P., Heier-Nielsen, S., Hylleberg, J., 1995. Late Holocene salinity fuctuations in Bjornsholm Bay, Limfjorden, Denmark, as deduced from micro- and macrofossil analysis. Holocene 5, 313^322.

Lario, J., 1996. Ultimo y Presente Interglacial en el area de conexiơn Atlăntico-Mediterrăneo: variaciones del nivel del mar, paleoclima y paleoambientes. Ph.D. Thesis, Universidad Complutense de Madrid, Madrid.

Lario, J., Zazo, C., Dabrio, C.J., Somoza, L., Goy, J.L., Bardaj申, T., Silva, P.G., 1995. Record of recent Holocene Sediment input on spit bars and deltas of south Spain. J. Coast. Res. 17, 241^245.

Lario, J., Zazo, C., Plater, J., Goy, J.L., Dabrio, C.J., Borja, F., Sierro, F.J., Luque, L., 2001. Particle size and magnetic properties of Holocene estuarine deposits from the Don ana Nacional Park (SW Iberia) : evidence of gradual and abrupt coastal sedimentation. Z. Geomorphol. 45, $33^{\wedge} 54$.

Lario, J., Spencer, C., Plater, J., Zazo, C., Goy, J.L., Dabrio, C.J., 2002. Particle size characterisation of Holocene backbarrier sequences from North Atlantic coasts (SW Spain and SE England). Geomorphology 42, 25^42.

Leduc, J., Bileodeau, G., Vernal, A., Mucci, A., 2002. Distribution of benthic foraminiferal populations in surface sedi-ments of the Saguinay Fjord, before and after the 1996

£ood. Palaeogeogr. Palaeoclimatol. Palaeoecol. 180, 207^ 223.

Luque, L., Lario, J., Zazo, C., Goy, J.L., Dabrio, C.J., Silva, P.G., 2001. Tsunami deposits as paleoseismic indicators: examples from the Spanish coast. Acta Geol. Hispan. 36 ,

$197^{\wedge} 211$.

Marocco, R., Melis, R., Montenegro, M.E., Pugliese, N., Vio, E., Lenardon, G., 1996. Holocene evolution of the Caorle barrier-lagoon (northern Adriatic Sea, Italy). Riv. Ital. Paleontol. Stratigr. $102,385^{\wedge} 396$.

Menanteau, L., 1979. Les Marismas du Guadalquivir. Exemple de transformation d'un paysage alluvial au cours du Quaternaire recent. These 3er Cycle, Paris-Sorbonne University, Paris.

Montenegro, M.E., Pugliese, N., 1996. Autoecological remarks on the ostracod distribution in the Marano and Grado Lagoons (Northern Adriatic Sea, Italy). Boll. Soc. Paleontol. Ital. 3, 123^132.

Morales, J.A., 1993. Sedimentologфa del estuario del rło Guadiana (S.O. Espan a-Portugal). Ph.D. Thesis, Sevilla University, Huelva.

Otvos, E.G., Price, W.A., 1979. Problems of chenier genesis and terminology $\wedge$ an overview. Mar. Geol. 31,

251^263. Penney, D.N., 1985. Application of ostracoda to sea-level

studies. Boreas 16, 237^247.

Pẹrez Quintero, J.C., 1989. Introducciőn a los Moluscos onubenses. I: Faun廿stica. Agencia del Medio Ambiente, Huelva.

Regnauld, H., 1999. L'elevation et les variations du niveau marin á l'Holocene terminal dans l'Ouest francais : una approche par les deppots de tempétes. Quaternaire 10, 181^ 188.

Rodrłguez-Ram¥rez, A., 1996. Geomorfologła continental y submarina del Golfo de Cadiz (Guadiana-Guadalquivir). Ph.D. Thesis, Huelva University, Huelva.

Rodrłguez-Ramłrez, A., 1998. Geomorfologфa del Parque Nacional de Don ana y su entorno. Organismo Autőnomo Parques Nacionales, Huelva.

Rodrłguez-Ramłrez, A., Rodrłguez-Vidal, J., Caceres, L., Clemente, L., Belluomini, G., Manfra, L., Improta, S., De 
Andres, J.R., 1996. Recent coastal evolution of the Don ana National Park (S. Spain). Quat. Sci. Rev. 15, 803^809.

Rodrфguez-Ram中rez, A., Rodrфguez Vidal, J., Clemente, L., Cåceres, L.M., 1997. Evoluciőn reciente de la red hidrogrăfica de las marismas del Guadalquivir. In : Rodr guez Vidal, J. (Ed.), Cuaternario Iberico. AEQUA, Huelva, pp. 137^ 139.

Rodrłguez-Ram¥rez, A., Căceres, L.M., Ruiz, F., Rodrłguez Vidal, J., 2001. Los 'cheniers' del estuario del Guadalquivir. Actas V Reun. Cuat. Iberr., pp. 226^229.

Ruiz, F., Gonzălez-Regalado, M.L., Serrano, L., Toja, J., 1996. Los ostră codos de las lagunas temporales del Parque

Nacional de Don ana. Aestuaria 4, 125^140.

Ruiz, F., Gonzălez-Regalado, M.L., Mun oz, J.M., 1997. Multivariate analysis applied to total and living fauna : seasonal ecology of recent benthic ostracoda o $i$ the North Cadiz Gulf Coast (SW Spain). Mar. Micropaleontol. 31, 183^203.

Ruiz, F., Gonzålez-Regalado, M.L., Baceta, J.I., MenegazzoVitturi, L., Pistolato, M., Rampazzo, G., Molinaroli, E., 2000a. Los ostråcodos de la laguna de Venecia (NE de Italia). Geobios 33, 447^454.

Ruiz, F., Gonzålez-Regalado, M.L., Baceta, J.I., Mun oz, JM., 2000b. Comparative ecological analysis of the ostracod faunas from low- and high-polluted Spanish estuaries : a multivariate approach. Mar. Micropaleontol. 40, 345^376.

Serrano, L., Toja, J., 1995. Limnological description of four temporary ponds in the Donana National Park (SW, Spain). Arch. Hydrobiol. 133, 497^516.
Stuiver, M., Reimer, P.J., 1993. Radiocarbon calibration program, Rev. 4.2. Radiocarbon $35,215^{\wedge} 230$.

Stuiver, M., Reimer, P.J., Bard, E., Beck, J.W., Burr, G.S., Hughen, K.A., Kromer, B., McCormac, F.G., v.d. Plicht, J., Spurk, M., 1998. INTCAL98 radiocarbon age calibration 24,000^0 ca BP. Radiocarbon 40, 1041^1083.

Umitsu, M., Buman, M., Kawase, K., Woodroje, C.D., 2001. Holocene paleoecology and formation of the Shoalhaven River deltaic-estuarine plains, southeast Australia. Holocene $11,407^{\wedge} 418$

Van der Kaars, S., Penny, D., Tibby, J., Dam, R.A.C., Suparan, P., 2001. Late Quaternary palaeoecology, palynology and palaeolimnology of a tropical lowland swamp: Rawa Danau, West-Java, Indonesia. Palaeogeogr. Palaeoclimatol. Palaeoecol. 171, 185^212.

Vanney, J.R., 1970. L'hydrologie du Bas Guadalquivir. Publicaciones Departamento Geograфa Aplicada C.S.I.C., Madrid.

Ybert, J.P., Mareschi Bissa, W., Martins Catharino, E.L., Kutner, M., 2003. Environmental and sea-level variations on the southeastern Brazilian coast during the Late Holocene with comments of prehistoric human occupation. Palaeogeogr. Palaeoclimatol. Palaeoecol. 189, 11^24.

Zazo, C., Goy, J.L., Somoza, L., Dabrio, C.J., Belluomini, G., Improta, S., Lario, J., Bardaji, T., Silva, P.G., 1994. Holocene sequence of sea-level £uctuations in relation to climatic trends in the Atlantic-Mediterranean linkage coast. J. Coast. Res. 10, 933^945. 